\title{
Skin Squamous Cell Carcinoma or Other Skin Carcinomas pN2b TNM Finding v7
}

National Cancer Institute

\section{Source}

National Cancer Institute. Skin Squamous Cell Carcinoma or Other Skin Carcinomas pN2b

TNM Finding v7. NCI Thesaurus. Code C88488.

Skin squamous cell carcinoma or other skin carcinomas with metastasis in multiple ipsilateral lymph nodes, none more than $6 \mathrm{~cm}$ in greatest dimension. (from AJCC 7th Ed.) 